\title{
TECHNICAL EFFICIENCY OF RICE FARMING DURING RAINY AND DRY SEASONS IN NGAWI DISTRICT OF EAST JAVA PROVINCE, INDONESIA
}

\author{
Saeri M.* \\ Assessment Institute for Agricultural Technology, East Java, Indonesia \\ Hanani N., Setyawan B., Koestiono D. \\ Faculty of Agriculture, University of Brawijaya, Indonesia \\ *E-mail: $\underline{\text { saerimoh@yahoo.com }}$
}

\begin{abstract}
The Aims of this study is to analyze the level of technical efficiency of rice farming in the rainy and dry seasons in Ngawi Regency, East Java Province. And compare the level of technical efficiency in the rainy and dry seasons. Respondents in this study were 88 rice farmers. Data analysis method used is Data envelopment analysis to obtain the level of technical efficiency of farmers and the average difference test ( $t$ test) to compare the level of technical efficiency in the rainy season and dry season. Tobit regression to analysis factors that influence technical efficiency. The results show that in the dry season farmers have higher technical efficiency than the rainy season. Similarly, the results of the average difference test (t test) show that the dry season has a higher average value of technical efficiency compared to the rainy season with a significant level of $1 \%$. Field schools, farmers group, distance of plants, seed quality and season have a significant effect on the technical efficiency. This implies that there needs to be an increase in knowledge related to rice farming in the rainy season so that it can improve the technical efficiency and productivity of rice farming in the rainy season.
\end{abstract}

\section{KEY WORDS}

Rice farming, technical efficiency, rainy season, dry season.

The technical efficiency of rice farming has an important role in maintaining domestic food security and also enhancing agricultural development in Indonesia. Rice is the staple food consumed by most Indonesians and per capita consumption shows that it is higher than neighboring countries (Heriqbaldi, et al., 2015). Besides that, Indonesia is known as the world's number three rice producer, which is as much as 70.8 million tons after China and India namely 206.5 million tons and 153.8 million tons, respectively. The contribution of Indonesian rice production to world rice production is $9.76 \%$. However, Indonesia is still the world's fourth largest rice importing country after China, the Philippines and Bangladesh, respectively: 2.5; 1.9; 1.3 and 1 million tons (FAO, 2015). This phenomenon occurs because there is still a lack of domestic rice supply, and also due to the relatively high rice consumption of the Indonesian population, because the development of the population is very high and the consumption of per capita is also very high, reaching $98 \mathrm{~kg} /$ capita / year (BPS, 2015). Therefore the government must continue to strive to make rapid efforts to achieve rice self-sufficiency. One effort that needs to be done is by increasing the technical efficiency of rice farming in Indonesia.

Research on technical efficiency in increasing the productivity of rice farming has been carried out. One of them is research conducted (Parichatnon et, al., 2016) in Thailand. The results showed that the relatively high level of technical efficiency in their production and environmental factors had a significant effect on technical efficiency. Previous research was also conducted by (Boubacar et, al., 2016) the results show that rice producers in southwest Niger can reduce their inputs by $52 \%$ and still produce the same level of rice production. The results obtained indicate that the average rice farmer can still reduce the input they use by $52 \%$ with the same amount of output, so that it can be technically efficient. Tobit regression 
shows that land area, experience, cooperative membership, main work and land ownership have a significant influence on technical efficiency. Ismail, Idris, Hassanpour (2013) researching the technical efficiency of rice farming in Malaysia by using a comparative analysis between VRS assumption Data Envelopment Analysis (DEA) and Stochastic Frontier Analysis (SFA). Input variables used are land area, seed costs, fertilizer costs, and the amount of labor, and pesticides. While the output variable used is rice production. The results of the analysis show that the average value of technical efficiency with DEA is 56 percent, this value is lower than the results of SFA which reached 69 percent. However, the results of several studies that have been carried out cannot be implemented in various seasons, such as the wet season and the rainy season. Because the level of technical efficiency of farming has a difference in each season. Therefore this study tries to fill the gap.

This study attempts to analyze the level of technical efficiency of rice farming in Indonesia with the Data Envelopment Analysis (DEA) approach in the rainy and dry seasons and compare the level of technical efficiency in both seasons. So that this research can be implemented in both seasons, especially in Indonesia.

\section{LITERATURE REVIEW}

Technical efficiency is the ability to avoid waste by producing as much output as possible with existing inputs and technologies or by using fewer inputs with the same technology will produce the same output. So that technical efficiency is using input as little as possible or producing as much output as possible. The producer is technically efficient if the increase in output is obtained through reducing at least one other output or increasing at least one input and if the decrease in an input is obtained through increasing one other input or decreasing at least one output. Therefore, producers who are technically efficient will be able to produce the same output with at least one fewer input or or using the same input will be able to produce at least one more output.

Technical efficiency is related to the ability of a company to produce on the isoquant frontier curve. Kumbhakar (2002) states that technical efficiency is the ability to minimize the use of production inputs a particular output vector or the ability to achieve maximum output from a particular input vector. A farmer is technically said to be more efficient than other farmers if the use of the same type and amount of inputs produces higher physical output.

Technical efficiency is associated with behavioral objectives to maximize output (Battese and Coelli 1995). Farmers are called technically efficient if they have produced at the level of production limits where this cannot always be achieved due to various factors such as bad weather, the presence of plant disturbing organisms or other factors that cause production to be below the expected limit (Battese and Coelli 1995).

The Data Envelopment Analysis (DEA) method was created as a performance evaluation tool for an activity that requires one or more types of inputs and produces one or more types of output. Measurements are simply expressed by the ratio between output to input which is a unit of measurement of efficiency or productivity that can be expressed parsia, for example output per hour, output per worker, etc., (Bambang, 2006). Example of the output of an entity: the proceeds of the sale of one or more types of goods, the production of an agricultural commodity (rice, corn, soybean, cabbage, carrots, bananas, durian etc.), profit of the company, profits from agricultural commodities and others) or in total (involving all outputs and all inputs of an entity into measurements) that can help show what input factors are most influential in producing an output. It's just that expanding the measurement of productivity from partial to total will bring difficulties in choosing what inputs and outputs should be included and how they are weighted (Cooper, 2002). The use of fixed weights that are applied uniformly to all inputs and outputs of the evaluated entity is known as the concept of "Total Factor Productivity" in the economy; this concept is contrary to the use of variable weights based on the best possible size for each entity evaluated in the method DEA (Cooper, 2002). 


\section{METHODS OF RESEARCH}

Determination of location is purposively with consideration the area is a center for rice commodities in East Java, both irrigated rice fields and rice plantations IP-300. Based on these considerations, the research location was chosen in Ngawi Regency.

The data used in this study are primary data and secondary data. The primary data collected from the results of interviews with farmers are data on farming carried out by farmers in dry and rainy season of 2016. The respondents used in this study were farmers who cultivated rice on technical irrigated rice fields with rice-paddy-rice cropping patterns (IPRice 300) in 2016.

The data collected included respondents' socio-economic conditions, farm performance, use of production inputs, farm income, farmer membership in agricultural programs and other information. The data is used to determine the level of efficiency and the factors that influence the technical efficiency of rice farming.

DEA method is a non-parametric method as a work evaluation tool for an activity that requires one or more inputs and produces one or more types of output, using linear program models as a method of measuring efficiency. The measurement is simply stated by the ratio of output to input which is a unit of measurement of efficiency or productivity that can be expressed partially (Cooper et al. 2006). Furthermore, Cooper et al (2006) explained that the DEA method uses technical mathematical programs that can handle many variables and constraints. In addition, the DEA method does not limit of inputs and outputs to be chosen because the techniques used can overcome them. Example of the output of an entity, such as the sale of one or more types of products, the production of an agricultural commodity, company profits, agricultural commodity farming profits etc.) or in total (involving outputs and inputs on an entity into measurements) which can indicate what input factors most influential in producing an output.

DMU (Decision Making Unit) is an organization or entity that will measure of efficiency relatively to a group of other homogeneous entities. Homogeneous means that the input and output of each DMU evaluated must be the same or similar. The DEA approach uses weighting that is fixed on all inputs and outputs of each DMU evaluated. The use of fixed weights that are applied uniformly to all inputs and outputs of the evaluated DMU is known as the concept of Total Factor Productivily. The concept of DEA was first carried out by Farrel (1957) and developed by Charnes, Cooper, and Rhodes (1978) known as the CCR model. In the CCR model the assumption used is a constant return to scale (CRS). The CRS assumption requires that a DMU be able to add or reduce input and output variables linearly without experiencing an increase or decrease in the value of efficiency. In its development, DEA experienced a modification that was first introduced by Banker, Charnes, and Cooper (1984), known as the BCC model. In the BCC model the assumption used is return to scale (VRS) variable. The VRS assumption is different from CRS, where VRS does not require changes in the input and output of a DMU to take place linearly, so increasing returns to scale and decreasing return to scale efficiency values (Cooper et al. 2006).

The CRS assumption is more appropriate when all DMUs work on an optimal scale. Whereas, the assumption of VRS is used when not all DMUs are on an optimal scale. Another difference between CRS and VRS is the calculation of the value of variation in efficiency with the size of the DMU scale. The assumption of VRS, DMU can be compared with another DMUs that are larger or smaller. This is not applied to the CRS assumption. Calculation of technical efficiency with the VRS model will obtain the value of efficiency scale in each DMU. The efficiency scale value of DMU can be calculated as the ratio between efficiency with the assumption of CRS or VRS from DMU. A DMU will be inefficient if there are differences in the value of CRS and VRS technical efficiency. In addition, it will be inefficient if the DMU only has pure technical efficiency, where the same efficiency value between CRS and VRS is ensured that the value of technical efficiency is smaller than one.

The model approach in this study is Data Envelopment Analysis (DEA). DEA is a work evaluation tool for an activity that uses one or more input types and produces one or more types of ouptut. Cooper et al (2006), defines DEA in a simple measurement expressed by the 
ratio between inputs to output and then can be expressed partially. The activity observed in the DEA model is to compare the input and output of each decision making unit (DMU) or decision-making unit. Each DMU will reflect diversity because of differences in the use of input combinations to produce different outputs. Comparison of input and output in the DMU is done to get an efficiency score. In this study, if the efficiency value is equal to one, then rice farming is relatively efficient. However, if the efficiency value is less than one, then rice farming is relatively inefficient.

There are several assumptions about using the DEA model according to Cooper et al (2006), namely the use of input and output results is a variable in the study, all decision making units (DMUs) must have the same input and output variables so that they can be analyzed, each DMU has a different choice of size and input to maximize efficiency individually, all input and output variables for each DMU are positive $(>0)$, and DEA is used as an analytical tool to measure performance at each DMU. The steps of work research using the DEA method according to Cooper et al (2006), namely identifying DMU observed with predetermined input and output variables and calculating efficiency values for each DMU to obtain the input and output variables that should be in order to achieve optimal performance. Farmers as decision-making units have control of the inputs used compared to the output produced, so that the DEA model in this study is oriented towards input variables. DEA model approach Variable Return to Scale is more appropriate to use. The equation of the VRS model is:

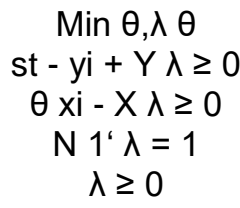

The assumption of this model is the ratio between the addition of input and output is not the same (variable return to scale). That is means, changes of the input and output of a DMU take place in a linear manner, so that permissible increases (increasing returns to scale / IRS) and decreasing returns to scale / DRS value of efficiency. So, this method involves multi input analysis, multi output, and variable return to scale. Input variables used were rice seeds, NPK fertilizer, urea fertilizer, SP-36, solid insecticides, liquid insecticides, and labor (labor in the family and labor outside the family). Meanwhile, the output variable used in this study consisted of rice production and rice productivity.

Tobit regression assumes that the variables are not free censored, only independent variables are unlimited. All of free and non-free variable, were measured correctly so that there was no perfect autocorrelation, heteroscedasticity, and multicollinearity and using the right mathematical model (Gujarati dan Dawn 2009). The Tobit regression model has several advantages, such as determine the intensity of factors that affect technical efficiency on farming, check the consistency of DEA results and identify explanatory variables (Cooper et al. 2006), and the influence of external variables on the production process can be tested both in terms of sign and significance (Gujarati dan Dawn 2009). The value of level technical efficiency with DEA analysis produced in this study is 0.00 to 1.00 , where the use of tobit regression will explain the relationship between the level of technical efficiency with the characteristics of the respondent farmers. The factors that influence technical efficiency are adjusted to the conditions of the respondents in the research location. The factors that are thought to influence the technical efficiency of rice farming, namely age, education, rice farming experience, number of family dependents, field schools, Farmers group, planting jark, seed quality, land ownership status and season. The tobit model used in this study is as follows:

$T E=\beta 0+\beta 1 X 1+\beta 2 X 2+\beta 3 X 3+\beta 4 X 4+\beta 5 X 5+\beta 6 X 6+\beta 7 X 7+\beta 8 X 8+\beta 8 X 8+\beta 9 X 9+\beta 10 X 10+\varepsilon$ 
Where: Dependent variable is Value of Technical Efficiency (TE) and the independent variables are age (X1), education (X2), experience of farming (X3), number of family dependents (X4), field school (X5), farmer group (X6), crop planting (X7), quality seed (X8), land ownership status (X9) and season (X10).

\section{RESULTS AND DISCUSSION}

Table 1 shows the differences in output and the use of dry season and rainy season inputs. Rice production in the dry season has a higher number than the rainy season. Besides that the highest difference in input use is the use of organic fertilizers where the use of organic fertilizers in the dry season is much higher than the rainy season. Interestingly, the average use of chemical fertilizers such as SP, Phons, and ZA during the rainy season is higher than the dry season.

Table 1 - Descriptive statistics

\begin{tabular}{|c|c|c|c|c|}
\hline \multirow[t]{2}{*}{ Variable } & \multicolumn{2}{|c|}{ Rainy season } & \multicolumn{2}{|c|}{ Dry seasons } \\
\hline & Mean & St.Dev. & Mean & St.Dev. \\
\hline Output & 6047.98 & 1111.58 & 6988.76 & 1048.02 \\
\hline Seed $(\mathrm{Kg})$ & 42.4546 & 11.7854 & 41.4091 & 13.456 \\
\hline Organic fertilizer $(\mathrm{Kg})$ & 792.705 & 954.559 & 1033.66 & 789.151 \\
\hline Urea $(\mathrm{Kg})$ & 255.148 & 85.2526 & 258.78 & 51.9214 \\
\hline SP $36(\mathrm{Kg})$ & 154.057 & 51.4172 & 137.419 & 22.6718 \\
\hline Phons (Kg) & 248.705 & 80.6014 & 239.681 & 64.2037 \\
\hline $\mathrm{ZA}(\mathrm{Kg})$ & 165.852 & 64.9032 & 160.994 & 39.6013 \\
\hline Leaf Fertilizer (Kg) & 2.88296 & 4.66701 & 2.90682 & 1.6435 \\
\hline Solid Pesticides (Kg) & 1.56023 & 0.90802 & 1.84318 & 1.26398 \\
\hline Liquid Pesticides (I) & 1.95568 & 1.64477 & 1.91364 & 2.12809 \\
\hline Labor (working hours) & 88.8102 & 22.1517 & 108.638 & 27.447 \\
\hline Irigation (hour) & 64.6591 & 42.0169 & 202.807 & 58.7251 \\
\hline
\end{tabular}
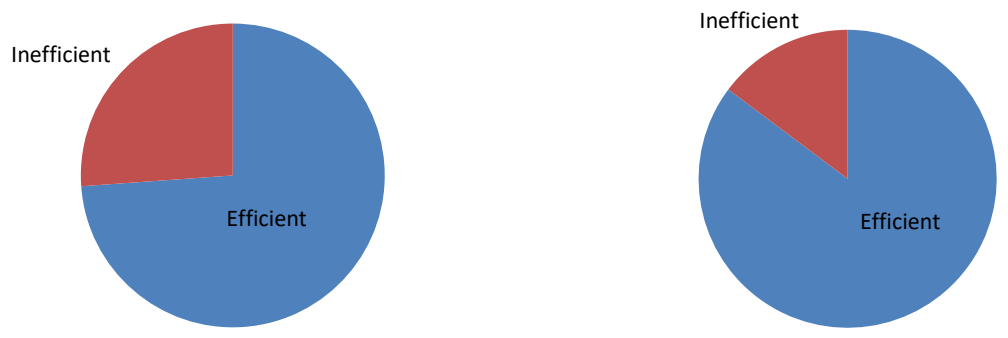

Figure 1 - Technical Efficiency of the Rainy Season and Dry Season, \%

The results of the Data Envelopment Analysis (DEA) show that in the dry season technically efficient farmers of $85 \%$ while farmers who are technically inefficient at $15 \%$. In the other hand, during the rainy season it shows that farmers who are technically efficient are $74 \%$, while farmers who are technically inefficient are $26 \%$. The average level of technical efficiency of rice farming in the dry season and rainy season can be carried out in table 2 . Where the dry season has an average of 0.994 while in the rainy season has an average of 0.978 . This shows that the level of technical efficiency of rice farming in the dry season is higher than in the rainy season.

Table 2 - Average technical efficiency

\begin{tabular}{cc}
\hline Season & Average technical efficiency \\
\hline Dry season & 0.994 \\
Rainy season & 0.978 \\
\hline
\end{tabular}


The results of different mean tests of technical efficiency of rice farming between the dry season and the rainy season can be see in the following table:

Table 3 - Test for Technical Efficiency Season 1 \& Rainy Season

\begin{tabular}{cccccc}
\hline \multirow{2}{*}{ Variable } & \multicolumn{2}{c}{ Dry Season 1 } & \multicolumn{2}{c}{ Rainy season } \\
\cline { 2 - 5 } & Mean & Std. Dev. & Mean & Std. Dev. & Significance \\
\hline Technical Efficiency & 0.9943295 & 0.0166862 & 0.9775114 & 0.0486975 & $0.0028^{\star * *}$ \\
\hline
\end{tabular}

Source: Primary data processed (2018).

From the results of the analysis of the difference mean test we can see that the technical efficiency of rice farming in season 1 and the rainy season has a significant difference. Where the level of technical efficiency in the dry season 1 has a higher level of technical efficiency with an average of 0.9943295 compared to the level of technical efficiency in the rainy season. This is because the use of inputs in the rainy season can still be reduced without changing rice production. this is in line with the research conducted by Coelli \& Battese (1996), where the level of technical efficiency of rice farming is strongly influenced by seasonal conditions. Besides that, the season is one of the factors that greatly affect the success of farmers in conducting farming, especially in the allocation of farmers in the use of rice farming inputs.

Based on the results of tobit regression analysis, can be seen that the variables of field schools, Farmers group, distance of plants, seed quality and season have a significant effect on the dependent variable (technical efficiency). Furthermore, the variables of age, education, experience, family dependence, land ownership status did not significantly effect on dependent variable, namely technical efficiency. More detail each variable effect to technical efficiency are as follows.

The field school has a positive and significant effect at the level of $1 \%$ to technical efficiency, its means the participation of farmers in field schools can improve the technical efficiency of rice farmers. Because in the field school activities the theory and practice of how to do rice farming will be given. The results of this study are in line with the findings of Linh et al (2017); Xiao et al (2015).

Table 4 - Factors that Influence Technical Efficiency

\begin{tabular}{lllll}
\hline Variable & Coef. & Std. Err & $T$ & $P>|t|$ \\
\hline Age & -0.00016 & 0.00032 & -0.500 & 0.617 \\
Education & 0.001345 & 0.001131 & 1.190 & 0.236 \\
Experience & 0.000161 & 0.000284 & 0.570 & 0.572 \\
Family Dependence & 0.002565 & 0.002586 & 0.990 & 0.323 \\
Field school & 0.010737 & 0.003007 & 3.570 & $0.000^{\star * *}$ \\
Farmers Group & 0.018072 & 0.009381 & 1.930 & $0.056^{\star *}$ \\
Space of Plant & 0.008984 & 0.004491 & 2.000 & $0.047^{* *}$ \\
Seed quality & 0.040121 & 0.006385 & 6.280 & $0.000^{\star * *}$ \\
Land ownership status & -0.00374 & 0.007005 & -0.530 & 0.594 \\
Season & 0.01762 & 0.004048 & 4.350 & $0.000^{\star * *}$ \\
cons & 0.894521 & 0.021704 & 41.210 & 0.000 \\
var(e.efisiensiteknis)| & $7.07 \mathrm{E}-05$ & 0.000536 & 0.000817 & \\
Log likelihood $=392.28273$ & & & & \\
Number of obs =176 & & & & \\
LR chi2 $=121.13$ & & & & \\
Prob $>$ chi2 $=0.0000$ & & & & \\
Pseudo R2 $=-0.1641$ & & & & \\
\hline
\end{tabular}

Description: ${ }^{*}=$ significant $10 \% .{ }^{* *}=5 \%$ significant. ${ }^{* * *}=$ significant $1 \%$.

Farmers group have a positive influence on the level of technical efficiency. The Farmers who join to Farmers group have a higher value of technical efficiency, because Farmers group are one of the facilities for farmers to increase their productivity. This result is in line with previous research, where participation in Farmers group has positive and 
significant effect on the efficiency of rice farming (Narendar et. al., 2018); (Asmara R. et. al., 2016)

Spacing of plant variable has a positive and significant effect at the level of $1 \%$ to technical efficiency, where the farmers who pay attention to their spacing, their technical efficiency will be higher. This is in accordance with conditions in the field where farmers who pay attention to spacing of plant have higher rice production than farmers who do not pay attention to the spacing of plant.

Seed quality variable has a positive and significant effect at the level of $1 \%$ on the technical efficiency of rice farmers. This implies that good seed quality will improve the technical efficiency of rice farming because the quality of seeds used to determine the quality and quantity of rice production, This result is in line with Kurniawan's (2015) that, seed quality has a positive influence on the technical efficiency of rice farmers.

Season variable has a significant influence at the level of $1 \%$ on the level of technical efficiency. Dry season, the level of technical efficiency of rice farmers tends to be higher than the rainy season this is in line with the expression of Coelli \& Battese (1996) where season is one of the factors that greatly influence the success of farmers in conducting farming, especially in allocating farmers to the use of farm inputs rice.

\section{CONCLUSION}

The results of the discussion that has been explained, it can be concluded that the dry season has an average of 0.994 while in the rainy season has an average of 0.978 . The dry season has a higher level of technical efficiency than the rainy season. On the other hand field schools, Farmers group, distance of plants, seed quality and season have a significant effect on the technical efficiency. Furthermore, the variables of age, education, experience, family dependence, land ownership status did not significantly effect on dependent variable, namely technical efficiency.

\section{REFERENCES}

1. Battese GE, Coelli TJ. 1995. A Model for Technical Inefficiency Effects in a Stochastic Frontier Production Function for Panel Data. Empirical Economics (20): 325 - 332.

2. Boubacar, O., Hui-qiu, Z., Rana, M. A., \& Ghazanfar, S (2016). Analysis on Technical Efficiency of Rice Farms and Its Influencing Factors in South-western of Niger. Journal of Northeast Agricultural University (English Edition), 23(4), 67-77. doi:10.1016/s10068104(17)30009-0

3. BPS Jatim. 2014. Jawa Timur Dalam Angka Tahun 2010-2014Buresh, R., D. Setyorini, S. Abdulrachman,F. Agus, C. Witt, I. Las dan Suyamto. 2006. Improving Nutrient Management For Irrigated Rice With Particular Consideration To Indonesia. Hal 165-178. Dalam.Sumarno et.al (Ed.). Rice Industry, Culture and Environment. Indonesian Center for Rice Reserch.

4. Cooper, et. al. 2002, Data Envelopment Analysis, New York.

5. FAO (Food and Agriculture Organization) of the United Nations, Rice Market Monitor, Volume XVIII Issue No. 2, July 2015.

6. Farrell MJ. 1957. The Measurement of Productive Efficiency. Journal of the Royal Statistical Society. 120 (3): $253-290$.

7. Gujarati, D. 1997. Basic Econometrics. Second Edition. Mc.Graw Hill Book Company. Singapore. $418 \mathrm{p}$.

8. Hassanpour B. 2013. Technical Efficiency Estimates of Paddy Farming in Peninsular Malaysia: A Comparative Analysis. Annals of Biological Research. 4 (5): $14-118$.

9. Kumbhakar CS. 2002. Specification and Estimation of Production Risk, Risk Preferences and Technical Efficiency. American Journal Agricultural Economic, 84(1):8-22.

10. Kurniawan A., Y (2012) Faktor-Faktor yang Mempengaruhi Efisiensi Teknis pada Usahatani Padi Lahan Pasang Surut di Kecamatan Anjir Muara Kabupaten Barito Kuala Kalimantan Selatan. Jurnal Agribisnis Perdesaan. Volume 02 Nomor 01 
11. Linh, L., T., Lee, P., P., Peng, K., C., and Chung R., H (2017). Factors Influencing Technical Efficiency of Rice Farms in Dong Thap Province, Vietnam: An Application of Two-Stage DEA. American-Eurasian J. Agric. \& Environ. Sci., 17 (3): 245-249,

12. Narendra, A., Hanani, N., Syafrial (2018) Factors That Influence Technical Efficiency Of Organic Paddy Farming In Sumberngepoh Village, Lawang Sub District, Malang District. Agricultural Socio-Economics Journal. Volume 18, Number 2 (2018): 79-85

13. Parichatnon S., Maichum K., Peng K., (2017). Evaluating Technical Efficiency Of Rice Production By Using A Modified Three-Stage Data Envelopment Analysis Approach: A Case Study In Thailand. International Journal of Scientific \& Technology Research Volume 6, Issue 01

14. Rhodes E. 1978. Measuring the Efficiency of Decision Making Units. European Journal of Operational Research. 2: 429 - 444.

15. Asmara, R., Hanani, N., Syafrial, S., \& Mustadjab, M. M. 2016. Technical Efficiency on Indonesian Maize Production: Frontier Stochastic Analysis (SFA) and Data Envelopment Analysis (DEA) Approach. Russian Journal of Agricultural and SocioEconomic Sciences (RJOAS), 10(58): 24-29

16. Xuejiao Wang, Haifeng Xiao (2015) Technical Efficiency and Its Influencing Factors of Farmers' Meat Sheep Production in China: Based on the Survey Data of Farmers. International Journal of Agricultural Economics. Vol. 1, No. 1, 2016, pp. 10-15. 